\title{
Tip variant focal segmental glomerulosclerosis associated with interferon- $\beta$ treatment of multiple sclerosis
}

\author{
Rhys Evans, ${ }^{1}$ Pandora Rudd, ${ }^{2}$ Paul Bass, ${ }^{1}$ Mark Harber ${ }^{1}$
}

${ }^{1} \mathrm{UCL}$ Centre for Nephrology، London, UK

${ }^{2}$ Whittington Hospital, London, UK

\section{Correspondence to} Dr Rhys Evans, rhysdrevans@gmail.com, rhys.evans3@nhs.net

\section{DESCRIPTION}

A 43-year-old Caucasian woman presented to the emergency department with a 1 -week history of swelling of her hands and feet. She had multiple sclerosis (MS) and had been treated with interferon- $\beta 1$ a (6 million units weekly subcutaneously) for the past 15 months without significant side effects. Other medical problems included migraine, oesophagitis, obesity and depression. There was no history of lithium use.

On examination, she was systemically well but hypertensive (199/110) with pitting oedema to the knee. Urine dipstick was positive for blood $(3+)$ and protein $(4+)$. Her creatinine was $64 \mu \mathrm{mol} / \mathrm{L}$, albumin $27 \mathrm{~g} / \mathrm{L}$, cholesterol $8.8 \mathrm{mmol} / \mathrm{L}$ and urinary protein:creatinine ratio (PCR) $1284 \mathrm{mg} / \mathrm{mmol}$, consistent with the nephrotic syndrome. Erythrocyte sedimentation rate was $62 \mathrm{~mm} / \mathrm{h}$ (C reactive protein $8 \mathrm{mg} / \mathrm{L}$ ) with an otherwise unremarkable renal screen, including negative HIV, hepatitis B and C serology. Renal biopsy demonstrated epithelial cell injury with foam cell accumulation at the tip of the glomerulus near the beginning of the proximal tubule, consistent with tip variant focal segmental glomerulosclerosis (FSGS; figure 1).

Her interferon- $\beta$ was stopped and she was treated with a ramipril $2.5 \mathrm{mg}$ once daily, frusemide $40 \mathrm{mg}$ once daily and tacrolimus $3 \mathrm{mg}$ twice daily initially, adjusted to a target level of $4-7 \mathrm{ng} / \mathrm{mL}$. Corticosteroids were not used due to their side effect profile and the patient's specific comorbidities.

Her proteinuria improved (latest urinary PCR $100 \mathrm{mg} / \mathrm{mmol}$ ), with resolution of her albumin and a reduction in cholesterol to $5.5 \mathrm{mmol} / \mathrm{L}$, but her creatinine rose to $119 \mu \mathrm{mol} / \mathrm{L}$ (figure 2A,B). Whether this is secondary to calcineurin inhibitor effect, her disease process or another factor is unclear. She remains off specific treatment for her MS without symptomatic relapse.

The nephrotic syndrome is a rare complication of treatment with interferon- $\beta$. Collapsing FSGS (in addition to minimal change disease and membranoproliferative glomerulonephritis) is a recognised pattern of glomerular injury. ${ }^{1-3}$ This is the first report

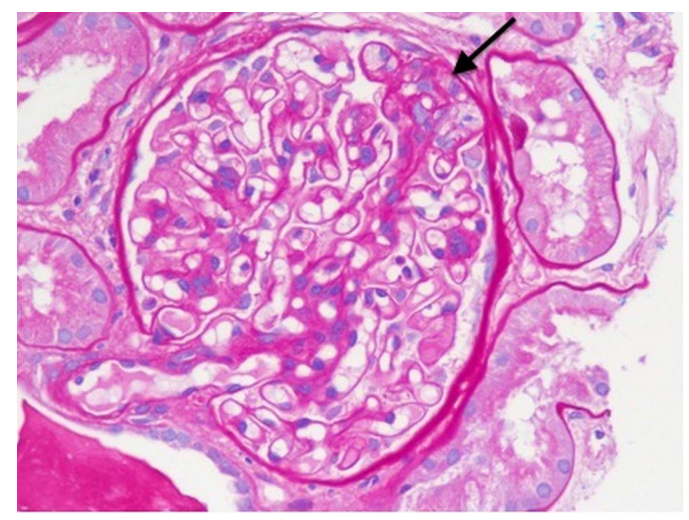

Figure 1 Renal biopsy (H\&E stain) demonstrating tip variant focal segmental glomerulosclerosis (arrowed). Epithelial cell injury with foam cell accumulation is seen at the tip of the glomerulus near the beginning of the proximal tubule.

of the nephrotic syndrome caused by tip variant FSGS in the setting of interferon- $\beta$ treatment. This morphological variant of FSGS is usually idiopathic (with high shear stress and tuft prolapse responsible for the morphogenesis) and has a favourable response to treatment. In this case, proteinuria significantly improved with cessation of interferon- $\beta$ and immunosuppression with tacrolimus.

\section{Learning points}

- The nephrotic syndrome is a rare complication of treatment with interferon- $\beta$.

- Tip variant and collapsing focal segmental glomerulosclerosis may be seen in the setting of interferon- $\beta$ treatment.

- It is important to recognise the morphological pattern of glomerular injury as this may affect outcome with more favourable responses seen with the tip as opposed to the collapsing variant.
To cite: Evans $R$, Rudd $P$, Bass P, et al. BMJ Case Rep Published online: [please include Day Month Year] doi:10.1136/bcr-2013203077 
Figure 2 Reduction in proteinuria (A) and rise in creatinine (B) with time after cessation of interferon- $\beta$ and treatment with ACE inhibitor, loop diuretic and tacrolimus.

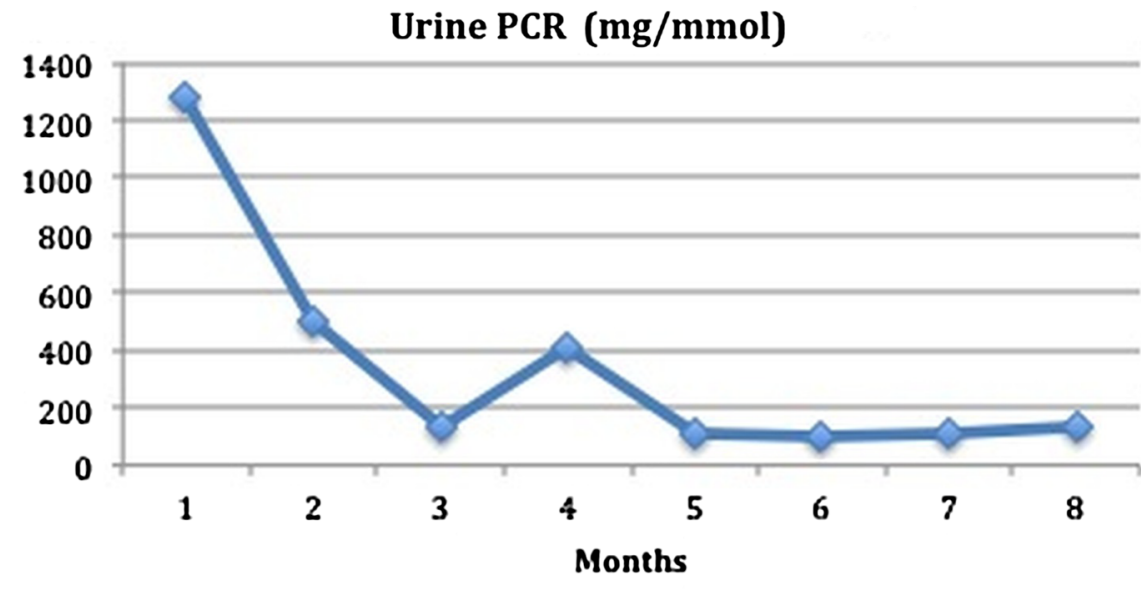

Creatinine $(\mu \mathrm{mol} / \mathrm{L})$

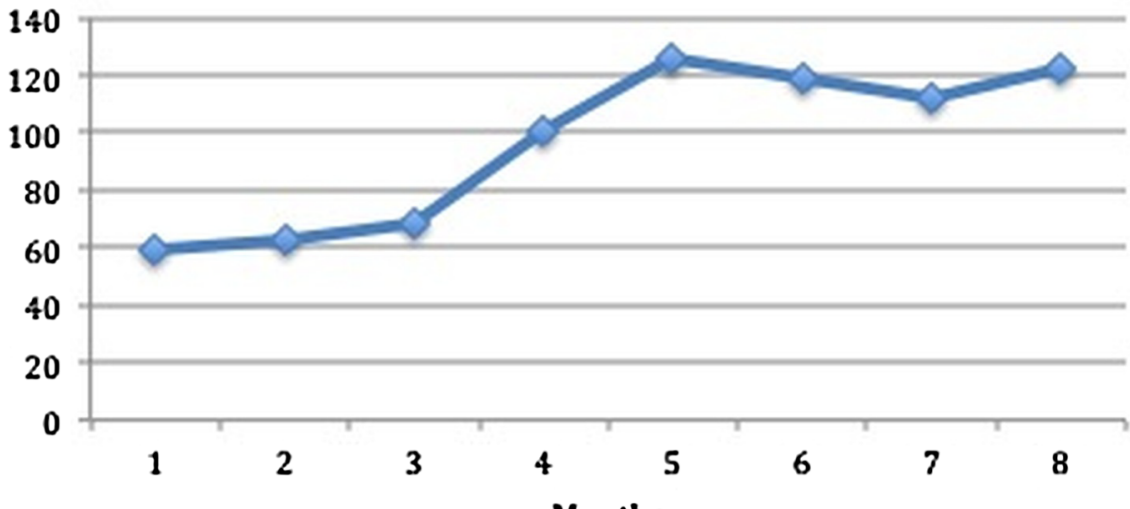

Months

Contributors $\mathrm{RE}, \mathrm{PR}$ and $\mathrm{MH}$ were equally clinically involved with the clinical care of the patient and preparation of the manuscript. PB prepared and reported the histology and reviewed the manuscript prior to submission. RE made corrections to the manuscript post initial submission.

Competing interests None.

Patient consent Obtained.

Provenance and peer review Not commissioned; externally peer reviewed.

\section{REFERENCES}

1 Wallbach M, Grone HJ, Kitze B, et al. Nephrotic syndrome in a multiple sclerosis patient receiving long-term interferon beta therapy. Am J Kidney Dis 2013; 61:786-9.

2 Markowitz GS, Nasr SH, Stokes MB, et al. Treatment with IFN-alpha, -beta, or -gamma is associated with collapsing FSGS. Clin J Am Soc Nephrol 2010;5:607-15.

3 Kumasaka R, Nakamura N, Shirato K, et al. Nephrotic syndrome associated with interferon-beta-1b therapy for multiple sclerosis. Clin Exp Nephrol 2006;10:222-5.

Copyright 2014 BMJ Publishing Group. All rights reserved. For permission to reuse any of this content visit http://group.bmj.com/group/rights-licensing/permissions.

BMJ Case Report Fellows may re-use this article for personal use and teaching without any further permission.

Become a Fellow of BMJ Case Reports today and you can:

- Submit as many cases as you like

- Enjoy fast sympathetic peer review and rapid publication of accepted articles

- Access all the published articles

- Re-use any of the published material for personal use and teaching without further permission

For information on Institutional Fellowships contact consortiasales@bmjgroup.com

Visit casereports.bmj.com for more articles like this and to become a Fellow 